\title{
Research Based Recommendations for Child Custody Evaluation Practices and Policies in Cases of Intimate Partner Violence
}

\section{Daniel G. Saunders Ph.D.}

To cite this article: Daniel G. Saunders Ph.D. (2015) Research Based Recommendations for Child Custody Evaluation Practices and Policies in Cases of Intimate Partner Violence, Journal of Child Custody, 12:1, 71-92, DOI: 10.1080/15379418.2015.1037052

To link to this article: http://dx.doi.org/10.1080/15379418.2015.1037052

$$
\text { 曲 Published online: 14 Jun } 2015 .
$$

\section{Submit your article to this journal ¿}

Џلll Article views: 196

Q View related articles ¿

\section{View Crossmark data ऍ}




\title{
Research Based Recommendations for Child Custody Evaluation Practices and Policies in Cases of Intimate Partner Violence
}

\author{
DANIEL G. SAUNDERS \\ School of Social Work, University of Michigan, Ann Arbor, Michigan
}

\begin{abstract}
This article reviews recent research on child custody evaluations in intimate partner violence (IPV) cases. Specifically, it covers assessment methods, evaluator selection, evaluator education, guidelines, differential assessment, and state policies. Special attention is given to new methods of bias reduction, the need to focus on coercive and controlling abuse, and the need to interpret psychological tests within a trauma framework. Recommendations are made in each area reviewed.
\end{abstract}

KEYWORDS bias reduction, assessment methods, domestic violence, custody evaluator education, evidence-based, family court

Recommendations for custody and visitation in cases involving intimate partner violence (IPV) need to be developed with extreme care. Victims and their children risk serious harm if sole or joint custody is awarded to a violent parent, or if that parent is not awarded custody but has poorly supervised visits (American Psychological Association, 1996; Hayes, 2012; Neustein \& Lesher, 2005; Radford \& Hester, 2006). Children risk being re-exposed to IPV or being directly abused both physically and psychologically (Hardesty \& Chung, 2006; Jaffe \& Crooks, 2007; Saunders, 2007). A small to substantial minority (between 10 and $39 \%$ ) of abusers receive primary physical or joint custody (Davis, O'Sullivan, Susser, \& Fields, 2011; Morrill, Dai, Dunn, Sung, \& Smith, 2005), or they might receive joint legal custody without physical custody (Bow \& Boxer, 2003; Saunders, Faller, \& Tolman, 2011), an arrangement that can have serious ramifications (Conner, 2011). Child custody evaluations are of central

Address correspondence to Daniel G. Saunders, Ph.D., Professor, School of Social Work, University of Michigan, 1080 South University Avenue, Ann Arbor, MI 48109-1106. E-mail: saunddan@umich.edu 
concern in the court's deliberations as, in contested cases, courts tend to place great weight on them (e.g., Davis et al., 2011).

Professionals often fail to detect IPV, but even when detected, its presence may make little difference in the outcome of a case (Pranzo, 2013). Record reviews and survivor interviews with representative samples have shown little or no difference in custody and visitation outcomes for cases with and without IPV (Kernic, Monary-Ernsdorff, Koepsell, \& Holt, 2005; Logan, Walker, Jordan, \& Horvath, 2002; O'Sullivan, 2000; O'Sullivan, King, Levin-Russell, \& Horowitz, 2006; Pranzo). Some evidence however indicates that evaluators are placing increasing weight on the presence of abuse and violence. In a 1996 study, 38\% of custody evaluators listed physical and sexual abuse as major reasons for sole custody (Ackerman \& Ackerman, 1996); in a similar study in 2008, 64\% listed these factors as reasons for sole custody (Ackerman \& Pritzl, 2011).

This article aims to summarize the latest research on child custody evaluation processes and policies in IPV cases. It covers new assessment tools for use by evaluators, guidance for courts in selecting evaluators, and information on training methods. However, more general IPV research is needed to help inform debates in the field. For example, victim advocates and family court professionals are often at odds over whether all domestic violence is the same and whether mediation and shared parenting should be allowed in some cases (Salem \& Dunford-Jackson, 2008). Researchers and practitioners also continue to debate the extent to which domestic violence is best described as violence against women and the extent to which it is best described as "mutual combat." For some, evidence that different patterns of abuse (e.g., mutual combat vs. male-to-female violence) are revealed in different types of samples has resolved this fundamental question (M. P. Johnson, 2008). But, others insist that when evaluators are taught that women are the primary victims, they may produce biased evaluation outcomes (D. G. Dutton, 2006). This review focuses primarily on male-to-female violence because of the evidence on gender bias presented below and because of evidence that: women use violence in self-defense more often than men, especially in lethal situations; women are more severely injured physically and psychologically than men; women are sexually assaulted and stalked at much higher rates than men; and women have more difficulty leaving violent relationships than men (Hamberger \& Larsen, 2015; Kimmel, 2002; Saunders, 2002). Some of the most rigorous studies show great gender disparities (Tjaden \& Thoennes, 2000). Within the custody evaluation context, there is also evidence of gender disparity. For example, custody evaluators - primarily psychologists in private practicereported their cases to be comprised of the following types: $51 \%$ male instigator, $17 \%$ bidirectional mostly male, $14 \%$ bidirectional mutual (both male and female instigators), $11 \%$ female instigator, and $7 \%$ bidirectional mostly female (Bow \& Boxer, 2003). A review of custody evaluation reports in two states showed similar gender disparities (Pranzo, 2013). 


\section{DETECTION OF ABUSE}

As in many other professional contexts, detection of abuse has been a major problem in the context of custody evaluations. In many custody-visitation proceedings, professionals fail to detect IPV (e.g., Araji \& Bosek, 2010; Davis et al., 2011; N. E. Johnson, Saccuzzo, \& Koen, 2005; Kernic et al., 2005; Voices of Women, 2008). Some survivors do not report abuse, even when asked. They may fear the report will be used against them, or their attorneys or mediators urge them not to report (O'Sullivan, 2000; Saccuzzo \& Johnson, 2004; Voices of Women). Rates of IPV detection differ considerably across jurisdictions, and these differences are likely the result of different court procedures. For example, rates have been shown to be much higher in courts with a self-report intake questionnaire (Keilitz et al., 1997).

In Bow and Boxer's (2003) nonrandom survey of 115 evaluators, most reported that they used multiple information sources. However, most $(60 \%)$ did not use specialized IPV questionnaires or instruments ("specialized inventories, measures, or questionnaires that focus specifically on domestic violence"). If IPV was detected, evaluators reported that it influenced their recommendations a great deal. In the Saunders et al. (2011) nonrandom survey of 465 evaluators, a very high percentage (89\%) reported that they always directly inquired about IPV, and another 5\% said they almost always (90-99\% of the time) asked about IPV. Regarding the use of "instruments or standard protocols to screen" for IPV, 38\% said they always used them; $37 \%$ said they never used them; and the remaining 23\% used them at rates varying from 5 to $95 \%$ of the time (average $=11 \%$ of the time; SD =9.2). As found in mediation and child protection settings (e.g., Ballard, Holtzworth-Munroe, Applegate, \& Beck, 2011; Magen, Conroy, Hess, Panciera, \& Simon, 2001), such protocols and instruments are likely to increase the odds of detecting IPV. Short versions of the Spouse Assault Risk Assessment and the Danger Assessment instruments have now been developed for front line workers (Campbell, 2015; Storey, Kropp, Hart, Belfrage, \& Strand, 2014). They provide specific, standardized questions and for some professionals, a handy prompt. Research in health care settings shows that professionals need only a few questions to detect IPV (Basile, Hertz, \& Back, 2007). Prefacing the questions with normalizing statements can be very helpful. For example, a statement like, "I don't know if this is (or ever has been) a problem for you, but many of the clients I see are dealing with abusive relationships. Some are too afraid or uncomfortable to bring it up themselves, so I've started asking about it routinely" (Family Violence Prevention Fund). Both skills training in detection and policy changes are likely to increase detection rates. Some states, among them California and Wisconsin, mandate that court-based evaluation centers include a question about IPV on intake forms. The success of training and policy changes on IPV and custody can be measured — as they have been in health and welfare settings-by comparing rates from anonymous within-agency 
surveys to record reviews, or by asking survivors if they have been asked about abuse (e.g., Hamberger, Saunders, \& Hovey, 1992). As evaluators implement screening, they also need to be reminded of the complexity and limitations of the screening process, for example reasons IPV may remain hidden after initial screening (Ver Steegh, Davis, \& Frederick, 2012).

\section{ASSESSMENT OF ABUSE}

\section{Lethality and Severe Violence}

Valid instruments are now available for assessing lethality risk. The potency section of the widely used $5 \mathrm{P}$ model developed by Johnston, Roseby, and Kuehnle (2009) for differentiating domestic violence (Potency, Pattern of Ongoing Violence/Coercive Control, Primary Perpetrator, Parenting Problems, Preferences/Perspective of the Child), which does not have established validity, can be replaced by the validated Danger Assessment index (Campbell, 2003) when assessing lethality potential. Other measures can be used to assess the risk of repeated severe or non-severe violence. The Ontario Domestic Assault Risk Assessment (Hilton \& Harris, 2008) and the Spousal Assault Risk Assessment (Kropp, 2009) are among the better-validated measures for non-lethal IPV. In the past, the Spousal Assault Risk Appraisal was the instrument most widely used by evaluators, though only 20\% actually employed it (Bow \& Boxer, 2003; Messing \& Thaller, 2012). Reviews of measures and protocols are also available (See Geffner, Conradi, Geis, \& Aranda, 2009; Gould \& Martindale, 2007; Hardesty \& Chung, 2006).

\section{Coercion and Control}

IPV researchers and practitioners are giving increasing attention to coercivecontrolling violence, in part because its effects go beyond those of physical abuse (Beck \& Raghavan, 2010). Evaluators who pay attention to coercivecontrolling violence in their assessments produce parenting plans with higher levels of safety (Davis et al., 2011) and are more likely to recommend custody for survivor-mothers (Saunders et al., 2011). Findings from the survey conducted by Saunders et al. indicate that $23 \%$ of evaluators focused on coercive-controlling aspects of a vignette in forming their assessment hypotheses. Such perspectives were related to IPV workshop attendance (Saunders et al., 2011) and more extensive IPV training (Haselschwerdt, Hardesty, \& Hans, 2011). A review of 18 evaluation reports revealed the problems with focusing on separate incidents of physical abuse without looking for patterns of controlling and coercive behavior (Pence, Davis, Beardslee, \& Gamache, 2012). 
Measures of controlling behavior sometimes rely on subscales of psychological abuse measures, for example, the Dominance-Isolation Subscale of the Psychological Maltreatment of Women Inventory (Tolman, 1999), the Multidimensional Measure of Emotional Abuse (Murphy \& Hoover, 1999), and the non-physical subscale of the Partner Abuse Scale (Hudson \& McIntosh, 1981). The 24-item Controlling Behaviors Scale (Graham-Kevan \& Archer, 2008) covers threats, intimidation, economic control, emotional control, and isolation. A scale of "controlling behavior" used in United States and Canadian national surveys of violence against women included such items as: "Tries to limit your contact with family and friends"; "Is jealous or possessive"; "Insists on knowing who you are with at all times"; "Calls you names or puts you down in front of others"; "Makes you feel inadequate"; "Shouts or swears at you"; "Prevents you from knowing about or having access to the family income even when you ask" (Statistics Canada, 2006; Tjaden \& Thoennes, 2000).

However, the face validity of measures needs to be carefully checked. Some items measure anger and verbal abuse more than control. The same can be said of measures of coercion. Many of the items on the $5 \mathrm{P}$ section called "Pattern of Ongoing Violence and Coercive Control" cover verbal abuse, substance abuse, contempt for authority, and other items outside of coercion, and this lack of precision suggests that it is an inadequate guide. M. A. Dutton and Goodman (2005), for example, define coercion as involving both a demand and a threat, but measures of coercion may not contain both elements. Their measure of coercion is well validated, but it contains 92 items and therefore is not very practical (Dutton, Goodman, \& Schmidt, 2006). Interview questions developed by Ehrensaft and Vivian (1999) might be especially useful in assessment. Examples are: "What happens when you try to make decisions that seem like your personal/private matters (like what to wear, how to handle something at work? How does your spouse react?"; "What kind of freedom does your husband/wife give you to decide for yourself the things that you want to do, places you want to go?"; and "In general, do you feel your husband/ wife tries to control you? Please explain." Similarly, an interview guide from the Battered Women's Justice Project (2013) includes items like: "I'd like to get a sense of how much freedom you have in your everyday life: To come and go as you please; to manage your own time; to make own decisions, etc." and "Is there anything that gets in your way of doing the things you want or need to do?" The Mediator's Assessment of Safety Issues and Concerns (MASIC), a measure developed for use by mediators (HoltzworthMunroe, Beck, \& Applegate, 2010), includes a Coercive Control Subscale, which seems suitable for use in a variety of settings. It includes items on restriction of activities and outside contacts, frequent checking from one's partner, and demands to obey. 


\section{Primary or Sole Aggressor}

Law enforcement officials are increasingly trained to identify the primary or sole aggressor when evidence exists that both partners have used force; indeed, they may be required by law to make such assessments. They are also increasingly able to look for evidence of long-term patterns of abuse from interviews or records when identifying the primary aggressor. They look in particular for "defensive wounds" inflicted by a survivor on the primary or sole aggressor. Help-seeking women are much more likely use violence in self-defense than for other motives (Bair-Merritt et al., 2010). In custody cases, a single act of self-defense on the survivor's part might frame the problem as "mutual combat" and remove violence of either party from consideration in the custody recommendation (Pranzo, 2013). A key to determining primary aggressor status is to ask each partner about fear levels and to assess each partner's level of post-traumatic stress disorder (PTSD). Reviews of clinical studies show much higher levels of fear and rates of PTSD in women than men when both have used force in the relationship (Hamberger, 2005; Hamberger \& Larsen, 2015).

\section{PSYCHOLOGICAL ASSESSMENT}

Despite the American Psychological Association's (2010) recommendation that psychologists employ diverse methods - including interviews, observations, information from collaterals, and official records - in the evaluation process, some appear to rely primarily on psychological testing. In the Saunders et al. (2011) survey, evaluators were asked to describe one or more instruments "to assess domestic violence"; $70 \%$ listed one or more IPV instruments (e.g., Conflict Tactics Scale, Spousal Assault Risk Appraisal, Danger Assessment Index), sometimes in conjunction with criminal record checks and measures of anger, substance abuse, and child abuse potential. However, $16 \%$ listed only a general measure of personality/psychopathology, most commonly the Minnesota Multiphasic Personality Inventory (MMPI). Evaluators using such general measures were more likely to believe that mothers make false allegations and to award sole or joint custody to the father in a case vignette. They had acquired less knowledge on IPV screening and danger assessment.

Men who batter do not have higher than normal rates of Axis I disorders, but many have Axis II disorders, including anti-social, borderline, dependent, and narcissistic disorders (Holtzworth-Munroe, Meehan, Herron, Rehman, \& Stuart, 2000). These may be difficult to detect on some psychological tests, and many abusers are adept at covering up serious childhood traumas that led to attachment and personality disorders. If personality disorders are detected in abusers, this information can help place them into typologies useful for danger assessment and intervention (Holtzworth-Munroe et al., 2000). 
Particular caution is required when interpreting test scores and survivors' behavior (Dalton, Drozd, \& Wong, 2006; Dutton, 1992; Rosewater, 1988). Examples of faulty interpretations exist in the literature (see, for example, Pence et al., 2012). The National Council of Juvenile and Family Court Judges (Dalton et al.) cautions:

Some of these standard tests may also measure and confuse psychological distress or dysfunction induced by exposure to domestic violence with personality disorder or psychopathology. While there may be cases in which trauma induced by abuse has a negative impact on parenting in the short term, it is critically important not to attach a damaging label prematurely to a parent whose functioning may improve dramatically once she or he is safe, the acute stress has been alleviated, and the trauma treated. (p. 21)

A trauma-focused lens is needed to interpret survivors' symptoms of depression and anxiety as reactions to violence and controlling behavior. Not only do survivors endure abuse during the relationship, they frequently experience prolonged harassment, threats, and abuse post-separation. They then face what is probably their worst nightmare: the prospect of losing a child to a known abuser. The stress can be overwhelming, and psychological symptoms are to be expected (Erickson, 2006).

Complex PTSD can be diagnosed in many survivors given the prolonged abuse, traumatic bonding, mixture of hopefulness and despair, and damaged sense of trust they may endure (Herman, 1997). Complex PTSD is characterized by several factors: difficulty regulating emotion, including suicidal thoughts, explosive anger or inhibited anger; variations in consciousness, for example, forgetting trauma and episodes of dissociation (feel detached from mind or body); negative self-perception such as shame, guilt, stigma, sense of being different; perception of the perpetrator as having total power; alterations in relations with others, including isolation and distrust; and loss of or changes in one's sense of meaning, such as loss of faith and sense of hopelessness and despair (Courtois, 2004; Herman).

Some of the aforementioned symptoms overlap with borderline and paranoid traits, which may be based in IPV experiences but more likely indicate a history of severe childhood abuse. As survivors reach safety, the symptoms of PTSD and depression normally decrease (Erickson, 2006). Irritability and anger, which are among possible PTSD symptoms, may be unexpected by professionals and also need to be placed in a trauma context. Evaluators seem swayed by the extralegal factor of a survivor's demeanor. In reacting to a case vignette, evaluators were five times more likely to award sole custody to the abuser if the survivor was portrayed as hostile (Hardesty, Hans, Haselschwerdt, Khaw, \& Crossman, 2015). They were also more likely to recommend this survivor to counseling, parenting classes, and anger 
management. The severity and type of abuse were not significantly linked to recommendations. Evaluation reports indicate that some survivors' fears underlie their guarded and negative behavior, which may then be interpreted by evaluators and judges as personality flaws (Pranzo, 2013).

\section{EVALUATOR EDUCATION}

Fifteen states require some form of training for evaluators and most evaluators report receiving at least some IPV training (Bow \& Boxer, 2003; Saunders et al., 2011). In a 2003 survey (Bow \& Boxer), nearly all had IPV education and they attended a median of four seminars and read a median of 18 books or articles regarding IPV. Gaining awareness of and reducing implicit gender, race, and class bias has received increased attention in judges' trainings. The same methods can be applied to evaluator training. Gender bias has been a particular concern in custody evaluations, as it is frequently uncovered in custody-disputes resolutions (Rosen \& Etlin, 1996). The bias is associated with mistrust of women and related in particular to the belief that they make false allegations of child abuse and domestic violence (Saunders et al., 2011). Dragiewicz (2010) provides a comprehensive summary of the many national, state, and local gender-bias reports pertaining to custody decisions. In addition to the tendency to disbelieve or minimize women's reports of abuse, or to disregard evidence for it, Dragiewicz also describes other problems uncovered during investigations. These include mothers being punished for reporting abuse, unfair financial settlements, and mothers being held to higher standards than fathers. In a study of appellate state court decisions, sole or joint custody was awarded to an alleged or adjudicated batterer in 36 of 38 cases, several of which involved severe battering and multiple convictions. However, two thirds of these cases were reversed on appeal (Meier, 2003).

Research shows the benefits of IPV training and knowledge acquisition. Knowledge is associated with believing that IPV is an important consideration in custody evaluations, false allegations are rare, safety needs to be emphasized over co-parenting, and a focus on coercive-controlling violence is important (Haselschwerdt et al., 2011; Saunders et al., 2011). In one survey, however, evaluators had less knowledge of post-separation violence, screening, and danger assessment than they did of other areas of knowledge acquisition (Saunders et al., 2011). The National Council of Juvenile and Family Court Judges' guidebook emphasizes:

Domestic violence is its own specialty. Qualification as an expert in the mental health field or as a family law attorney does not necessarily include competence in assessing the presence of domestic violence, its impact on those directly and indirectly affected by it, or its implications for the parenting of each party. And even though some jurisdictions are now requiring custody evaluators to take a minimum amount of training in 
domestic violence, that "basic training" by itself is unlikely to qualify an evaluator as an expert, or even assure basic competence, in such cases. (Dalton et al., 2006, p. 17)

The guidebook suggests testing an evaluator's level of experience and expertise with questions about IPV training and the number of IPV cases the evaluator has handled. A report for the National Center for State Courts (NCSC) (Keilitz et al., 1997) makes a number of additional recommendations, including being sure that any roster of court-approved evaluators reflects the cultural composition of the community and assessing whether the evaluator has potential misconceptions or biases about IPV.

Using evidence-based methods, the National Center for State Courts has done extensive training for court personnel on bias reduction (NCSC, 2012), focusing on implicit bias (For a review see Kang et al., 2012). Increasing awareness of implicit bias through implicit bias tests is likely to help professionals challenge their own explicit biases. The largest implicit bias project is Project Implicit, a collaboration of three universities. It has online implicit bias tests on gender, race, and other topics (https://implicit.harvard.edu/ implicit/index.jsp). The organization Understanding Prejudice also offers implicit bias tests for gender and race and has many resources (http:// www.understandingprejudice.org/iat/index2.htm). In addition to building awareness of bias, the NCSC recommends:

Routinely check thought processes and decisions for possible bias (i.e., adopt a thoughtful, deliberative, and self-aware process for inspecting how one's decisions are made); Identify sources of stress and reduce them in the decision-making environment; Identify sources of ambiguity and impose greater structure in the decision-making context; Institute feedback mechanisms; Increase exposure to stereotyped group members (e.g., seek out greater contact with the stigmatized group in a positive context). (p. 15)

Evaluation texts and trainings increasingly focus on inspection of one's values and biases (Drozd, Oleson, \& Saini, 2013; Gould \& Martindale, 2007), in particular knowledge of "confirmatory bias" (beginning with a hypothesis and finding facts that fit with it). A disconfirmatory stance is needed with the goal of trying to disprove each hypothesis.

The link between attitudes about custody and sexist beliefs and the belief the world is just indicates a connection to evaluators' deeper values (Saunders, Tolman, \& Faller, 2013). Evaluators can explore core values using the Terminal Values Inventory of Ball-Rokeach (1976). This values clarification inventory focuses on freedom (e.g., individual rights of parents) versus equality (e.g., equality between parents) versus safety (of all family members). Values exploration dovetails with implicit bias work, because the latter enhances the value placed on equality. An explicit understanding of such core beliefs 
can support evaluators in changing their attitudes by creating dissonance between core beliefs (terminal values) and attitudes (Grube, Mayton, \& Ball-Rokeach, 1994). It can also assist in gaining a deeper understanding of the connection between attitudes and behavior (Crano \& Prislin, 2006; Wray, 2006). Evaluator training can be made personally relevant by using such thought experiments as picturing a relative, friend, or co-worker as a survivor in a custody conflict. Cognitive change is likely to follow such emotional connections with survivors in a way that may mimic the beliefs and responses of professionals who have relatives who are survivors (Saunders et al., 2011).

Personally knowing a survivor of IPV can be an important background variable for evaluators. For example, in the survey of evaluators conducted by Saunders et al. (2011) participants with family members who survived IPV were more likely to believe that IPV is important in custody-visitation determinations and that mothers do not make false IPV allegations. Further, knowing a friend who was a victim of IPV was related to the belief that alleged IPV victims do not make false IPV allegations and do not alienate children from the other parent. Hearing accounts from survivors during evaluator training sessions can be done in a variety of ways, among them interactive theater (e.g., Praxis International's play, Will You Hold My Child?), survivor speaker's panels, and documentaries (e.g., "Small Justice", "Family Court Crisis - Our Children at Risk," and "Battered Mother's Testimony Project")

A frequent evaluator training topic is the effect of IPV on children, including tools for measuring the effect (Edleson, Shin, \& Johnson Armendariz, 2008). However, without training on the economic and psychological traps that hold survivors in or pull them back into abusive relationships, professionals can be quick to assert that the survivor has harmed the child by staying in the relationship. A major reason survivors leave IPV relationships is concern over the effect of violence on children. Counter-intuitively, they may also stay out of concern for the children. Reasons for staying for the children's sake include: fearing financial loss; believing the children need their father; fear of losing custody to a potential child abuser; fear she and the children will be stalked, abused and/or killed; and family pressures (Hardesty \& Chung, 2006; Hardesty \& Ganong, 2006). In addition to understanding IPV's effect on children and the traps that hold victims in IPV relationships, evaluator training should present research to show that many children have protective factors in their environment that lead to resiliency and no serious problems (Gewirtz \& Edleson, 2007). Practices and policies must reflect these distinctions in order to avoid inappropriate "failure-to-protect" charges.

\section{EVALUATOR SELECTION}

Discretion regarding the choice of custody evaluators exists in some jurisdictions. For example, a county might have established an approved list 
of evaluators from which it chooses. Not surprisingly, the extent of IPV training is a major criterion for selection of custody evaluators. The relative lack of bias is also an important factor in evaluator selection (Keilitz et al., 1997). One form of bias or misinformation is indicated by evaluators' uncritical use of parent alienation theories. False assumptions may be made that allegations, especially from mothers, are likely false and do not need to be investigated and that parents must cooperate with each other and communicate directly (For examples of such assumptions contained in evaluation reports see Pence et al., 2012). A tendency to believe that survivor-mothers make false allegations and alienate the children from their ex-partners has been found to be associated with sexist beliefs and the belief the world is basically a just place (Saunders et al., 2011). These beliefs are also related to recommendations that abusive fathers be given sole or joint custody or unsupervised visits. The National Council of Juvenile and Family Court Judges' guidebook cautions:

In contested custody cases, children may indeed express fear of, be concerned about, have distaste for, or be angry at one of their parents. Unfortunately, an all too common practice in such cases is for evaluators to diagnose children who exhibit a very strong bond and alignment with one parent and, simultaneously, a strong rejection of the other parent, as suffering from "parental alienation syndrome" or "PAS." Under relevant evidentiary standards, the court should not accept this testimony. The theory positing the existence of "PAS" has been discredited by the scientific community. If the history of violence is ignored as the context for the abused parent's behavior in a custody evaluation, she or he may appear antagonistic, unhelpful, or mentally unstable. Evaluators may then wrongly determine that the parent is not fostering a positive relationship with the abusive parent and inappropriately suggest giving the abusive parent custody or unsupervised visitation in spite of the history of violence; this is especially true if the evaluator minimizes the impact on children of violence against a parent or pathologizes the abused parent's responses to the violence. (Dalton et al., 2006, pp. 24-25)

Even without explicit reference to PAS or alienation, evaluators may use an implicit alienation framework when assessing motives and behavior (Pranzo, 2013).

Professional background might also be relevant in evaluator selection. Some studies find that the majority of judges and attorneys prefer psychologists to social workers as custody evaluators (Bow \& Quinnell, 2004; LaFortune, 1997). However, social workers' evaluations may include a broader systems framework (e.g., Lewis, 2009) that focuses more on family interactions, community supports, and social norms, including those leading to inequities. One study of all forms of custody evaluations found that social workers were more likely than psychologists to make home visits, but less likely to observe 
the mother and child (Horvath, Logan, \& Walker, 2002). In a vignette study (Hardesty et al., 2015), compared with psychologists, attorneys and social workers were more likely to recommend custody to survivors over joint custody. In the Saunders et al. (2011) survey, evaluators with degrees in social work were more likely than psychologists and counselors to recommend custody to the victim. Social workers were more likely than psychologists to see supervised rather than unsupervised visits for the abusive father in an IPV vignette as beneficial. Social workers were also more likely than psychologists to believe that IPV is an important factor when making custody-visitation decisions and that victims do not tend to make false allegations, alienate children, or hurt them when they resist co-parenting. Social work evaluators may have more supportive responses to victims because their training emphasizes the community, sociocultural, and social-justice context of the family, and they may be more likely to see psychological symptoms within the context of trauma history.

\section{GUIDELINES AND TEMPLATES}

Judges and evaluators seem increasingly aware of the need to establish clear expectations for the form and content of reports, as well as the processes and methods needed to conduct an evaluation. Such standardization is strongly recommended by NCSC (Keilitz et al., 1997), and many standards and guidelines have been developed for custody evaluators and supervised visitation monitors. Most commonly cited are guidelines issued by the American Psychological Association (2010), the Association of Family and Conciliation Courts (2006), and the Supervised Visitation Network (2006). One group of practitioners recommends custody evaluation guidelines for clinical social workers (Luftman, Veltkamp, Clark, Lannacone, \& Snooks, 2005). Some nonprofit organizations, such as Child Abuse Solutions also provide templates that can help guide evaluators (http://www.childabusesolutions.com/). One highly specific set of guidelines is found in California law and administrative code (California Judicial Branch, 2014). It requires court-based evaluators to go beyond detection; they must also provide safety planning such as discussion of safe housing, workplace safety, safety for other family members and children, access to financial resources, and information about local domestic violence agencies. Ellis (2008) recommends mandatory risk assessment that includes safety planning and has developed a measure for that purpose.

\section{NEGATIVE IMPACT OF JOINT LEGAL CUSTODY}

Although evaluators most commonly recommend that sole legal and physical custody be awarded to victims of IPV, some studies show a relatively high rate of joint legal custody recommendations (Bow \& Boxer, 2003; Saunders et al., 2011). However, as Conner (2011) concludes in a lengthy review of 
the literature: "Communication is made difficult, if not impossible, when one parent harasses, abuses, and intimidates the other parent. Not only are batterers poor decision makers, they also tend to use the power of joint parenting to exert control over the other parent" (p. 260). Research supports Conner's conclusion that many abusers will use a joint legal custody arrangement to continue harassment and manipulation through legal channels (Bancroft \& Silverman, 2002; Hayes, 2012; Jaffe, Lemon, \& Poisson, 2003; Zorza, 2010). Abusers can gain access to victims by manufacturing reasons to "discuss" child rearing or by insisting upon joint attendance at school events, parent-teacher meetings, or medical appointments. They can also withhold consent for a child's counseling, medical procedures, and extra-curricular school events. Conner recommends sole legal custody with the survivor who can share information about the child on a secure website to which the ex-partner cannot respond.

\section{DIFFERENTIAL ASSESSMENT AND RECOMMENDATIONS}

Recent research on different types of domestic violence (Holtzworth-Munroe et al., 2000; M. P. Johnson, 2008; Swan \& Snow, 2002) has been used to suggest that more individualized guidelines for custody and visitation decisions could be beneficial (See Jaffe \& Crooks, 2007; Jaffe, Johnston, Crooks, \& Bala, 2008; special issues of Family Court Review; Olson \& Ver Steegh, 2008; and Journal of Child Custody, 2009, Vol. 6). The different types of domestic violence described are (a) coercive-controlling forms of violence that tend to be chronic and severe (often referred to as "battering" or "patriarchal terrorism") and (b) violence that appears to arise from conflicts within the relationship and tends to be non-severe ("situational couple" violence). Separation-instigated violence is a third type of violence recently described, although it has much less empirical support than the previous two (M. P. Johnson; Stark, 2009). A single incident of minor violence during the separation process is likely to be seen much differently than repeated, severe, coercive violence (Gould, Martindale, \& Eidman, 2008). However, scholars debate whether such minor violence is typical of separation violence and whether attention to minor violence could lead to complacency (Dalton, 1999; Stark), given the increased risk for domestic homicide after separation, in some cases with no prior violence (Nicolaidis et al., 2003). Misconceptions and ambiguities about "situational violence" exist as well, and more research is needed to understand this type of violence (M. P. Johnson). Despite increased attention to distinguishing situational-couple and coercivecontrolling violence in publications for evaluators, responses to a vignette revealed that the type of violence (conflict-based vs. control-based) did not result in differential outcomes and most evaluators recommended joint custody (Hans, Hardesty, Haselschwerdt, \& Frey, 2014). 
Regarding situational violence, it is important to note that, contrary to some descriptions, it is not necessarily mutual. Furthermore, M. P. Johnson's (2008) typology is based on behavioral distinctions and does not include psychological dimensions that may be much better at predicting post-separation violence. Some of M. P. Johnson's cautions and more nuanced points do not appear in publications and training materials used by evaluators. For example, findings of many studies indicate that the coercive-controlling type of abuser consists of two very distinct types (Holtzworth-Munroe et al., 2000). The first is an anti-social type, likely to have a long criminal history and dismissive attachment style; the second, a borderline type not likely to have an extensive criminal history, seeks out help, and has a preoccupied attachment style with a fear of abandonment. This latter type is likely to have a higher risk of intimate partner homicide than the anti-social type (Saunders \& Browne, 2000).

\section{STATE AND NATIONAL STATUTES}

Various state laws may directly or indirectly affect evaluators' recommendations. There is evidence that a "friendly-parent" provision (the standard requiring a parent to facilitate a good relationship with the other parent), together with statutes presuming joint custody, tend to override presumptions against awarding joint legal custody to the abuser (Morrill et al., 2005). Fortunately, some states provide exemptions to the application of the friendly-parent factor in cases of domestic violence. Although every state lists IPV as a factor to consider when determining the best interests of the child, nothing prevents decision-makers from giving extra weight to IPV. Indeed, several states now require that it be given extra weight. Some states have a rebuttable assumption that the offender should not be awarded custody, but these laws often have limitations, such as requiring a higher standard of proof.

Statutes also address other issues related to custody and visitation. These often include: standards for supervised visitation and exchange programs; exempting domestic violence cases from mandated mediation; protecting battered women from charges of child abandonment if they flee for safety without their children; and making it easier for victims to relocate for safety reasons. Some innovations have been implemented in a few states. For example, a mediated agreement can be declined by the court if domestic violence affected the victim's ability to make the agreement (National Council of Juvenile and Family Court Justice, 2005). Moreover, if a parent alleges that a child is abused or exposed to domestic violence, such allegations cannot be used against the parent bringing the allegation (National Council of Juvenile and Family Court Judges, 2004). A useful exercise for evaluators is to consider how each best interest factor in their state statutes might indirectly 
involve IPV. For example, factors might include the moral fitness of the parents; the length of time that the child has lived in a stable, satisfactory environment; and the capacity and disposition of each parent to give the child love, affection, and guidance. The indicators for such standards are likely to be tied to the behavior of an abuser, whether the child is abused directly or not.

Other countries have additional legal protections. New Zealand, for example, includes a broad definition of domestic violence that incorporates "various tactics of power and control that perpetrators commonly employ," including "threats, intimidation, harassment, damage to property" (Busch \& Robertson, 2000, p. 274). It also specifies protection for domestic violence victims from the accusation that they failed to protect their children from the abuser (Jaffe et al., 2003), stating that, "the person who suffers the abuse is not regarded as having allowed the child to see or hear the abuse." The 1995 law included a requirement that the court consider safety measures for the victim when the abuser is granted visitation (Jaffe et al., 2003); and to weigh specific criteria such as the likelihood of further violence and emotional harm to the child (Busch \& Robertson, 2000). However, these clauses were removed in 2014. Beyond the use of statutes, an international human rights perspective can be applied (Silverman, Mesh, Cuthbert, Slote, $\&$ Bancroft, 2004). International conventions and treaties for the safety and well-being of women and children can increase government accountability when applied to individual cases and to the analysis of state and national policies (Silverman et al.).

\section{SUMMARY}

During the extremely difficult and complex decision-making process of evaluating custody-visitation cases, evaluators and policymakers need the latest research to guide them-particularly when factoring in the added risks present in IPV cases. This article provides some research-based guidance in a number of areas: detection, assessment, evaluator selection, evaluator education, bias reduction, practice guidelines, and state statutes. The conscientious application of research findings to evaluation practices and policies is likely to lead to increased safety and wellbeing for all family members.

\section{REFERENCES}

Ackerman, M. J., \& Ackerman, M. C. (1996). Child custody evaluation practices: A 1996 survey of psychologists. Family Law Quarterly, 30(3), 565-586.

Ackerman, M. J., \& Pritzl, T. B. (2011). Child custody evaluation practices: A 20-year follow-up. Family Court Review, 49, 618-628. doi:10.1111/j.1744-1617.2011. 01397.x 
American Psychological Association. (1996). Violence and the family: Report of the american psychological association presidential task force on violence and the family. Washington, DC: American Psychological Association.

American Psychological Association. (2010). Guidelines for child custody evaluations in family law proceedings. American Psychologist, 65, 863-867. doi:10.1037/a0021250

Araji, S. K., \& Bosek, R. L. (2010). Domestic violence, contested child custody, and the courts: Findings from five studies. In M. Hannah \& B. Goldstein (Eds.) Domestic violence, abuse, and child custody: Legal strategies and policy issues (pp. 1-34). Kingston, NJ: Civic Research Press.

Association of Family and Conciliation Courts. (2006). Model Standards of Practice for Child Custody Evaluation. Retrieved from http://www.afccnet.org/ resources/standards_practice.asp

Bair-Merritt, M. H., Crowne, S. S., Thompson, D. A., Sibinga, E., Trent, M., \& Campbell, J. (2010). Why do women use intimate partner violence? A systematic review of women's motivations. Trauma, Violence, \& Abuse, 11(4), 178-189. doi: $10.1177 / 1524838010379003$

Ballard, R. H.; Holtzworth-Munroe, A., Applegate, A. G., \& Beck, C. J. A. (2011). Detecting intimate partner violence in family and divorce mediation: A randomized trial of intimate partner violence screening. Psychology, Public Policy, and Law, 17, 241-263. doi:10.1037/a0022616

Ball-Rokeach, S. J. (1976). Receptivity to sexual equality. The Pacific Sociological Review, 19, 519-540. doi:10.2307/1388835

Bancroft, L., \& Silverman, J. (2002). The batterer as parent: Addressing the impact of domestic violence on family dynamics. Thousand Oaks, CA: SAGE Publications.

Basile, K. C., Hertz, M. F., \& Back, S. E. (2007). Intimate partner violence and sexual violence victimization assessment instruments for use in healthcare settings: Version 1. Atlanta, GA: Centers for Disease Control and Prevention, National Center for Injury Prevention and Control.

Battered Women's Justice Project. (2013, April 23). Unpublished document from New Jersey Superior Court Family Education Conference, Galloway, NJ.

Beck, C. J. A., \& Raghavan, C. (2010). Intimate partner abuse screening in custody mediation: The importance of assessing coercive control. Family Court Review, 48(3), 555-565. doi:10.1111/j.1744-1617.2010.01329.x

Bow, J. N., \& Boxer, P. (2003). Assessing allegations of domestic violence in child custody evaluations. Journal of Interpersonal Violence, 18(12), 1394-1410. doi: $10.1177 / 0886260503258031$

Bow, J. N., \& Quinnell, F. A. (2004). Critique of child custody evaluations by the legal profession. Family Court Review, 42, 115-127. doi:10.1111/j.174-1617.2004. tb00637.x

Busch, R., \& Robertson, N. (2000). Innovative approaches to child custody and domestic violence in New Zealand: The effects of law reform on the discourses of battering. Journal of Aggression, Maltreatment \& Trauma, 3(1), 269-299. doi:10.1300/J146v03n01_17

California Judicial Branch. (2014). California Rules of Court. Rule 5.215. Domestic violence protocol for Family Court Services. Retrieved from http://www.courts. ca.gov/cms/rules/index.cfm?title=five\&linkid=rule5_215 
Campbell, J. C. (2003). Danger assessment. Retrieved from http://www. dangerassessment.org/

Campbell, J. C. (2015). Danger Assessment-5. Retrieved from http://www. dangerassessment.org/uploads/DA-5_2.26.15.pdf

Conner, D. H. (2011). Back to the drawing board: Barriers to joint decision-making in custody cases involving intimate partner violence. Duke Journal of Gender Law \& Policy, 18, 223.

Courtois, C. A. (2004). Complex trauma, complex reactions: Assessment and treatment. Psychotherapy: Theory, Research, Practice, Training, 41(4), 412425. doi: $10.1037 / 0033-3204.41 .4 .412$

Crano, W. D., \& Prislin, R. (2006). Attitudes and persuasion. Annual Review of Psychology, 57, 345-374.

Dalton, C. (1999). When paradigms collide: Protecting battered parents and their children in the family court system. Family Court Review, 37, 273-296. doi:10.1111/j.174-1617.1999.tb01306.x

Dalton, C., Drozd, L., \& Wong, F. (2006). Navigating custody and visitation evaluations in cases with domestic violence: A judge's guide. Reno, NV: National Council of Juvenile and Family Court Judges.

Davis, M. S., O'Sullivan, C. S., Susser, K., \& Fields, M. D. (2011). Custody evaluations when there are allegations of domestic violence: Practices, beliefs and recommendations of professional evaluators. Final Report submitted to the National Institute of Justice, November 29, 2010. Retrieved from www.ncjrs.gov/ $\mathrm{p}+$ dffiles1/nij/grants/234465.pdf

Dragiewicz, M. (2010). Gender bias in the courts: Implications for battered mothers and their children. In M. Hannah \& B. Goldstein (Eds.), Domestic violence, abuse, and child custody: Legal strategies and policy issues (pp. 5.1-5.18). Kingston, NJ: Civic Research Institute.

Drozd, L. M., Olesen, N. W., \& Saini, M. (2013). Parenting plan and child custody evaluations: Increasing competence and preventing avoidable errors. Sarasota, FL: Professional Resource Press.

Dutton, D. G. (2006). Domestic abuse assessment in child custody disputes: Beware the domestic violence research paradigm. Journal of Child Custody, 2, 23-42. doi:10.1300/J190v02n04_02

Dutton, M. A. (1992). Understanding women's responses to domestic violence: A redefinition of battered woman syndrome. Hofstra Law Review, 21, 1191.

Dutton, M. A., \& Goodman, L. A. (2005). Coercion in intimate partner violence: Toward a new conceptualization. Sex Roles, 52(11-12), 743-756. doi:10.1007/ s11199-005-4196-6

Dutton, M. A., Goodman, L., \& Schmidt, R. J. (2006). Development and validation of a coercive control measure for Intimate Partner Violence: Final technical report. Retrieved from https://www.ncjrs.gov/pdffiles1/nij/grants/700214438.pdf

Edleson, J. L., Shin, N., \& Johnson Armendariz, K. K. (2008). Measuring children's exposure to domestic violence: The development and testing of the Child Exposure to Domestic Violence (CEDV) scale. Children and Youth Services Review, 30(5), 502-521. doi:10.1016/j.childyouth.2007.11.006

Ehrensaft, M. K., \& Vivian, D. (1999). Is partner aggression related to appraisals of coercive control by a partner? Journal of Family Violence, 14(3), 251-266. 
Ellis, D. (2008). Divorce and the family court: What can be done about domestic violence? Family Court Review, 46(3), 531-536.

Erickson, N. S. (2006). Use of the MMPI-2 in child custody evaluations involving battered women: What does psychological research tell us? Family Law Quarterly, 39(1), 87-108.

Geffner, R., Conradi, L., Geis, K., \& Aranda, M. B. (2009). Conducting child custody evaluations in the context of family violence allegations: Practical techniques and suggestions for ethical practice. Journal of Child Custody, 6(3-4), 189-218. doi:10.1080/15379410903084608

Gewirtz, A. H., \& Edleson, J. L. (2007). Young children's exposure to intimate partner violence: Towards a developmental risk and resilience framework for research and intervention. Journal of Family Violence, 22(3), 151-163. doi:10.1007/ s10896-007-9065-3

Gould, J. W., \& Martindale, D. A. (2007). The art and science of child custody evaluations. New York, NY: Guilford.

Gould, J. W., Martindale, D. A., \& Eidman, M. H. (2008). Assessing allegations of domestic violence. Journal of Child Custody, 4, 1-35. doi:10.1300/J190v04n01_01

Graham-Kevan, N., \& Archer, J. (2008). Does controlling behavior predict physical aggression and violence to partners? Journal of Family Violence, 23(7), 539548. doi:10.1007/s10896-008-9162-y

Grube, J. W., Mayton, D. M., \& Ball-Rokeach, S. J. (1994). Inducing change in values, attitudes, and behaviors: Belief system theory and the method of value self-confrontation. Journal of Social Issues, 50(4), 153-173. doi:10.1111/ j.1540-4560.1994.tb01202.x

Hamberger, L. K. (2005). Men's and women's use of intimate partner violence in clinical samples: Toward a gender-sensitive analysis. Violence and Victims, 20(2), 131-151. doi:10.1891/0886-6708.2005.20.2.131

Hamberger, L. K., \& Larsen, S. E. (2015). Men's and women's experience of intimate partner violence: A review of ten years of comparative studies in clinical samples: Part 1. Journal of Family Violence, 1-19.

Hamberger, L. K., Saunders, D. G., \& Hovey, M. (1992). Prevalence of domestic violence in community practice and rate of physician inquiry. Family Medicine, 24(4), 283-287.

Hans, J. D., Hardesty, J. L., Haselschwerdt, M. L., \& Frey, L. M. (2014). The effects of domestic violence allegations on custody evaluators' recommendations. Journal of family psychology, 28(6), 957-966. doi:10.1037/fam0000025

Hardesty, J. L., \& Chung, G. H. (2006). Intimate partner violence, parental divorce, and child custody: Directions for intervention and future research. Family Relations, 55(2), 200-210. doi:10.1111/j.1741-3729.2006.00370.x

Hardesty, J. L., \& Ganong, L. H. (2006). How women make custody decisions and manage co-parenting with abusive former husbands. Journal of Social and Personal Relationships, 23(4), 543-563. doi:10.1177/0265407506065983

Hardesty, J. L., Hans, J. D., Haselschwerdt, M. L., Khaw, L., \& Crossman, K. A. (2015). The influence of divorcing mothers' demeanor on custody evaluators' assessment of their domestic violence allegations. Journal of Child Custody, 12(1), 47-70.

Haselschwerdt, M. L., Hardesty, J. L., \& Hans, J. D. (2011). Custody evaluators' beliefs about domestic violence allegations during divorce: Feminist and family 
violence perspectives. Journal of Interpersonal Violence, 26, 1694-1719. doi: $10.1177 / 0886260510370599$

Hayes, B. E. (2012). Abusive men's indirect control of their partner during the process of separation. Journal of Family Violence, 27, 333-344. doi:10.1007/ s10896-012-9428-2

Herman, J. L. (1997). Trauma and recovery. New York, NY: Basic Books.

Hilton, N. Z., \& Harris, G. T. (2008). How nonrecidivism affects predictive accuracy: Evidence from a cross-validation of the Ontario Domestic Assault Risk Assessment (ODARA). Journal of Interpersonal Violence, 24(2), 326-337. doi: $10.1177 / 0886260508316478$

Holtzworth-Munroe, A., Beck, C. J. A., \& Applegate, A. G. (2010). The mediator's assessment of safety issues and concerns (MASIC): A screening interview for intimate partner violence and abuse available in the public domain. Family Court Review, 48, 646-662. doi:10.1111/j.1744-1617.2010.001339.x

Holtzworth-Munroe, A., Meehan, J. C., Herron, K., Rehman, U., \& Stuart, G. L. (2000). Testing the Holtzworth-Munroe and Stuart (1994) batterer typology. Journal of Consulting and Clinical Psychology, 68(6), 1000-1019. doi:10.1037/ 0022-006x.68.6.1000

Horvath, L. S., Logan, T., \& Walker, R. (2002). Child custody cases: A content analysis of evaluations in practice. Professional Psychology: Research and Practice, 33, $557-565$.

Hudson, W. W., \& McIntosh, S. R. (1981). The assessment of spouse abuse: Two quantifiable dimensions. Journal of Marriage and the Family, 873-888.

Jaffe, P. G., \& Crooks, C. V. (2007). Assessing the best interests of the children. In J. L. Edleson \& O. J. Williams (Eds.) Parenting by men who batter: New directions for assessment and intervention (pp. 45-64). New York, NY: Oxford University Press.

Jaffe, P. G., Johnston, J., Crooks, C. V., \& Bala, N. (2008). Custody disputes involving allegations of domestic violence: The need for differentiated approaches to parenting plans. Family Court Review, 46, 500-522. doi:10.1111/j.1744-1617. 2008.00216.x

Jaffe, P., Lemon, N., \& Poisson, S. (2003). Child custody and domestic violence. Thousand Oaks, CA: SAGE Publications.

Johnson, M. P. (2008). A typology of domestic violence: Intimate terrorism, violent resistance, and situational couple violence. Boston, MA: Northeastern University Press.

Johnson, N. E., Saccuzzo, D. P, \& Koen, W. J. (2005). Child custody mediation in cases of domestic violence: Empirical evidence of a failure to protect. Violence Against Women, 11(8), 1022-1053. doi:10.1177/1077801205278043

Johnston, J. R., Roseby, V., \& Kuehnle, K. (2009). In the name of the child: A developmental approach to understanding and belping children of conflicted and violent divorce. New York, NY: Springer Publishing.

Kang, J., Bennett, M., Carbado, D., Casey, P., Dasgupta, N., Faigman, D., \& Mnookin, J. (2012). Implicit bias in the courtroom. UCLA Law Review, 59(5), 1124-1186.

Keilitz, S. L., Davis, C. V., Flango, C. R., Garcia, V., Jones, A. M., Peterson, M., \& Spinozza, D. M. (1997). Domestic violence and child custody disputes: A resource handbook for judges and court managers. Williamsburg, VA: National Center for State Courts. 
Kernic, M. A., Monary-Ernsdorff, D. J., Koepsell, J. K., \& Holt, V. L. (2005). Children in the crossfire: Child custody determinations among couples with a history of intimate partner violence. Violence Against Women, 11(8), 991-1021. doi: $10.1177 / 1077801205278042$

Kimmel, M. S. (2002). "Gender symmetry" in domestic violence: A substantive and methodological research review. Violence Against Women, 8(11), 1332-1336. doi: $10.1177 / 107780102237407$

Kropp, P. R. (2009). Intimate partner violence risk assessment. In J. L. Ireland, C. Ireland, \& P. Birch (Eds.), Violent and sexual offenders: Assessment, treatment and management (pp. 43-67). Cullompton, UK: Willan Publishing.

LaFortune, K. A. (1997). An investigation of mental health and legal professionals' activities, beliefs, and experiences in domestic court: An interdisciplinary survey. (Unpublished doctoral dissertation). University of Tulsa, Tulsa, Oklahoma.

Lewis, K. (2009). Child custody evaluations by social workers. Washington, DC: National Association of Social Workers.

Logan, T. K., Walker, R., Jordan, C. E., \& Horvath, L. S. (2002). Child custody evaluations and domestic violence: Case comparisons. Violence and Victims, 17(6), 719-742. doi:10.1891/vivi.17.6.719.33718

Luftman, V. H., Veltkamp, L. J., Clark, J. J., Lannacone, S., \& Snooks, H. (2005). Practice guidelines in child custody evaluations for licensed clinical social workers. Clinical Social Work Journal, 33, 327-357. doi:10.1007/s10615-005-4947-4

Magen, R. H., Conroy, K., Hess, P. M., Panciera, A., \& Simon, B. L. (2001). Identifying domestic violence in child abuse and neglect investigations. Journal of Interpersonal Violence, 16, 580-601. doi:10.1177/088626001016006006

Meier, J. S. (2003). Domestic violence, child custody, and child protection: Understanding judicial resistance and imagining the solutions. American University Journal of Gender, Social Policy, and Law, 11, 702.

Messing, J. T., \& Thaller, J. (2012). The average predictive validity of intimate partner violence risk assessment instruments. Journal of Interpersonal Violence, 28, 1537-1558.

Morrill, A. C., Dai, J., Dunn, S., Sung, I., \& Smith, K. (2005). Child custody and visitation decisions when the father has perpetrated violence against the mother. Violence Against Women, 11(8), 1076-1107. doi:10.1177/107780120 5278046

Murphy, C. M., \& Hoover, S. A. (1999). Measuring emotional abuse in dating relationships as a multifactorial construct. Violence and Victims, 14(1), 39-53.

National Center for State Courts. (2012). Addressing implicit bias in the courts. Retrieved from http://www.ncsc.org/ /media/Files/PDF/Topics/Gender\%20 and\%20Racial\%20Fairness/IB_Summary_033012.ashx

National Council of Juvenile and Family Court Judges. (2004). Family violence: Legislative update (Vol. 10). Reno, NV: Author.

National Council of Juvenile and Family Court Judges. (2005). Family violence: Legislative update (Vol. 11). Reno, NV: Author.

Neustein, A., \& Lesher, M. (2005). From madness to mutiny: Why mothers are running from the family courts-And what can be done about it. Lebanon, $\mathrm{NH}$ : Northeastern University Press. 
Nicolaidis, C., Curry, M. A., Ulrich, Y., Sharps, P., McFarlane, J., Campbell, D., ... Campbell, J. (2003). Could we have known? A qualitative analysis of data from women who survived an attempted homicide by an intimate partner. Journal of General Internal Medicine, 18, 788-94. doi:10.1046/j.1525-1497.2003. 21202.x

Olson, K. B., \& Ver Steegh, N. (2008). Introduction of special issue editors. Family Court Review, 46, 434-436.

O'Sullivan, C. S. (2000). Estimating the population at risk for violence during child visitation. Domestic Violence Report, 5(5), 65.

O'Sullivan, C. S., King, L. A., Levin-Russell, K., \& Horowitz, E. (2006). Supervised and unsupervised parental access in domestic violence cases: Court orders and consequences. Final technical report submitted to the National Institute of Justice.

Pence, E., Davis, G., Beardslee, C., \& Gamache, D. (2012). Mind the gap: Accounting for domestic abuse in child custody evaluations1. Minneapolis, MN: Battered Women's Justice Project.

Pranzo, D. (2013). Child custody and visitation disputes in Sweden and the United States: A study of love, justice, and knowledge. Plymouth, England: Lexington Books.

Radford, L., \& Hester, M. (2006). Mothering through domestic violence. London, UK: Jessica Kingsley Publishers.

Rosen, L. N., \& Etlin, M. (1996). The hostage child: Sex abuse allegations in custody disputes. Bloomington, IN: Indiana University Press.

Rosewater, L. B. (1988). Battered or schizophrenic?: Psychological tests can't tell. In K. Yllö, Kersti, \& M. Bograd (Eds.), Feminist perspectives on wife abuse (pp. 200-216). Thousand Oaks, CA: Sage.

Saccuzzo, D. P., \& Johnson, N. E. (2004). Child custody mediation's failure to protect: Why should the criminal justice system care? National Institute of Justice Journal, 251, 1-30.

Salem, P., \& Dunford-Jackson, B. L. (2008). Beyond politics and positions: A call for collaboration between family court and domestic violence professionals. Family Court Review, 46(3), 437-453. doi:10.1111/j.1744-1617.2008.00213.x

Saunders, D. G. (2002). Are physical assaults by wives and girlfriends a major social problem? A review of the literature. Violence Against Women, 8, 1424-1448. doi:10.1177/107780102237964

Saunders, D. G. (2007). Child custody and visitation decisions in domestic violence cases: Legal trends, risk factors, and safety concerns. Minneapolis, MN: VAWnet, National Resource Center on Domestic Violence. Retrieved from http://new. vawnet.org/category/Main_Doc.php?docid=1134

Saunders, D. G., \& Browne, A. (2000). Intimate partner homicide. In R. T. Ammerman \& M. Hersen (Eds.), Case studies in family violence (2nd ed., pp. 415-449). New York, NY: Plenum.

Saunders, D. G., Faller, K. C., \& Tolman, R. M. (2011). Child custody evaluators' beliefs about domestic abuse allegations: Their relationship to evaluator demographics, background, domestic violence knowledge, and custody visitation recommendations. Final technical report to the National Institute of Justice. Retrieved from https://www.ncjrs.gov/pdffiles1/nij/grants/238891.pdf 
Saunders, D. G., Tolman, R. M., \& Faller, K. C. (2013). Factors associated with child custody evaluators' recommendations in cases of intimate partner violence. Journal of Family Psychology, 27(3), 473.

Silverman, J. G., Mesh, C. M., Cuthbert, C. V., Slote, K., \& Bancroft, L. (2004). Child custody determinations in cases involving intimate partner violence: A human rights analysis. American Journal of Public Health, 94, 951-957. doi:10.2105/ AJPH.94.6.951

Stark, E. (2009). Rethinking custody evaluation in cases Involving domestic violence. Journal of Child Custody, 6, 287-321. doi:10.1080/15379410903084707

Statistics Canada. (2006). Measuring violence against women: Statistical trends 2006. Ottawa, Canada: Statistics Canada. Retrieved from http://www.statcan.gc.ca/ pub/85-570-x/85-570-x2006001-eng.htm

Storey, J. E., Kropp, P. R., Hart, S. D., Belfrage, H., \& Strand, S. (2014). Assessment and management of risk for intimate partner violence by police officers using the brief spousal assault form for the evaluation of risk. Criminal Justice and Behavior, 41(2), 256-271.

Supervised Visitation Network. (2006). Standards for supervised visitation practice. Retrieved from http://www.svnetwork.net/standards.asp

Swan, S. C., \& Snow, D. L. (2002). A typology of women's use of violence in intimate relationships. Violence Against Women, 8(3), 286-319. doi:10.1177/ 107780120200800302

Tjaden, P., \& Thoennes, N. (2000). Extent, nature, and consequences of intimate partner violence: Findings from the National Violence against Women Survey. Report sponsored by the National Institute of Justice. Retrieved from https:// www.ncjrs.gov/App/Publications/abstract.aspx?ID=181867

Tolman, R. M. (1999). The validation of the Psychological Maltreatment of Women Inventory. Violence and Victims, 14(1), 25-37.

Ver Steegh, N., Davis, G., \& Frederick, L. (2012). Look before you leap: Court system triage of family law cases involving intimate partner violence. Marquette Law Review, 95, 955-990. Retrieved from http://scholarship.law.marquette.edu/ mulr/vol95/iss3/11

Voices of Women. (2008). Justice denied: How family courts in NYC endanger battered women and children. Brooklyn, NY: Voices of Women Organizing Project, Battered Women's Resource Center. Retrieved from www.vowbwrc.org

Wray, R. J. (2006). Public health communication theory and strategies for interpersonal violence prevention. Journal of Aggression, Maltreatment \& Trauma, 13, 41-60.

Zorza, J. (2010). Batterer manipulation and retaliation compounded by denial and complicity in the family courts. In M. Hannah \& B. Goldstein (Eds.), Domestic violence, abuse, and child custody: Legal strategies and policy issues (pp. 14-2-14-28). Kingston, NJ: Civic Research Press. 